\title{
Suitability of Anaerobic Digesters for West Africa: Nigeria as a Case Study
}

\author{
Cynthia Okoro-Shekwaga K. and N. Horan
}

\begin{abstract}
West Africa comprises 16 countries including Nigeria. In Nigeria, there are two seasons; the dry season where midday temperature surpasses $38^{\circ} \mathrm{C}$ and rainy season with midday temperature as low as $12^{\circ} \mathrm{C}$. Agricultural losses are generated from every step of food and animal processing due to low technological adoption. Most West African countries have very high fraction of organic components in their waste stream (up to 56 percent) and are currently disposed of in dumpsites and in some cases uncontrolled landfills. The average temperature, food and animal waste are major potentials for the anaerobic digester with energy recovery. An economic appraisal of a dumpsite in Nigeria was carried out using the net present value (NPV) technique and adopting a shadow price of carbon of \$10 (1, 557 naira). A negative NPV of $\sim$ \$0.36million $(56,107,144.33$ naira) was calculated. Also a substantial portion of land can be reclaimed by adopting anaerobic digesters.
\end{abstract}

Index Terms-Anaerobic digestion, clean development mechanism, landfill, West Africa.

\section{INTRODUCTION}

West Africa is a region in Africa between the latitudes $4^{\circ} \mathrm{N}$ and $28^{\circ} \mathrm{N}$ and longitudes $15^{\circ} \mathrm{E}$ and $16^{\circ} \mathrm{W}$. It comprises 16 countries namely; Ghana, Guinea, Guinea-Bissau, Ivory Coast, Liberia, Mali, Mauritania, Niger, Gambia, Senegal, Sierra Leone, Benin, Cape Verde, Togo, Nigeria and Burkina-Faso [1]. Nigeria has a land area of $923,768 \mathrm{~km}^{2}$ and borders the gulf of guinea, between Benin on the west and Cameroon on the east [2].

In Nigeria, two seasons are experienced; they are the rainy and dry season. The average annual temperature in Nigeria is reported between $15^{\circ} \mathrm{C}$ to about $35^{\circ} \mathrm{C}$. An approximate of 70 percent of the populace engages in subsistent agriculture, even with the advent of oil boom [2]. A large variety of Agricultural products are grown in Nigeria and this is influenced by the climatic variations in the country. The staple food includes corn, yam, coco-yam, cowpeas, beans, millets, sweet potatoes, cassava, plantain, banana, rice and also varieties of fruits and vegetables [2].

Population movement from dispersed geographical areas and settling together in communities defined the need to carry out proper and efficient treatment and disposal of waste by humans [3]. Nigerian population is constantly on the increase (Fig. 1), so also the eating habits and consequently the generated waste. Therefore a number of treatment

Manuscript received April 14, 2014; revised June 5, 2014.

Cynthia Okoro-Shekwaga is with the Federal University of Technology, Minna, Nigeria. She is currently with the University of Leeds, United Kingdom (e-mail: cn12cko@leeds.ac.uk).

Nigel Horan is with the University of Leeds, United Kingdom (e-mail: n.j.horan@leeds.ac.uk). methods have to be employed to collect and treat waste, for which the sole aim should be to improve environmental sustenance and as much as possible recover energy.

It was reported that an average range of $0.66 \mathrm{~kg} / \mathrm{cap} / \mathrm{d}$ of waste in urban areas to $0.44 \mathrm{~kg} / \mathrm{cap} / \mathrm{d}$ in rural areas is generated in Nigeria [4]. With a population of 166.21 million, the daily waste generated is about $107,700,000 \mathrm{~kg}$ in urban areas and $73,100,000 \mathrm{~kg}$ in rural areas respectively; the major part of the waste being organic [4].

This research identifies the waste handling methods employed by most West African countries, Nigeria as a case study and how unreliable these methods have become in handling the generated solid waste. The availability of high organic waste fractions and heat within the region gives the potential for energy generation with the use of clean technologies. It therefore shows the need to embrace anaerobic digestion for waste management and energy creation in West African countries.

\section{MeTHODOLOGY}

Solid waste management systems in Nigeria were reviewed from available literature. This was done to analyze the technology gap in the approaches currently being adopted by most West African countries. An economic appraisal of a landfill in Minna, Niger state, Nigeria was carried out as a case study, using the net present value (NPV) technique. There was no data on the waste generation or composition for the state, therefore data from a neighboring state (Makurdi) with similar population density, economic status and food production was adopted. In computing the net present value, the shadow price of carbon (SPC) was used to quantify the environmental effect of carbon emissions, as defined in the clean development mechanism (CDM). A SPC of \$10 (1,557 naira) was adopted from Stern's estimate [5]. A 15 year period net present value of the landfill was calculated and the result was analyzed.

\section{A. Waste Handling Scheme in Nigeria}

In Nigeria, governments have now put in measures to keep waste out of the street under the administration of state and local environment agencies, through daily street sweeping and routine waste collection from waste bins situated along major streets and in some cases, residential areas [4]. This so far has been helpful, as the ugly sights and inconvenience posed by the waste have to a great extent been eliminated from the streets. The ultimate question becomes how do we manage these waste generated and collected routinely from the streets? It is not enough to just remove these waste from their point and non-point sources, something has to be done to them to obtain a right balance. 
Waste management technologies which include pyrolysis, incineration, and composting, landfilling, and anaerobic digestion amongst others, has landfill at the bottom of the hierarchy (Fig. 2) [3], yet landfilling remains the most commonly used waste management strategy around the world, used to be described as a 'child of convenience' [6].

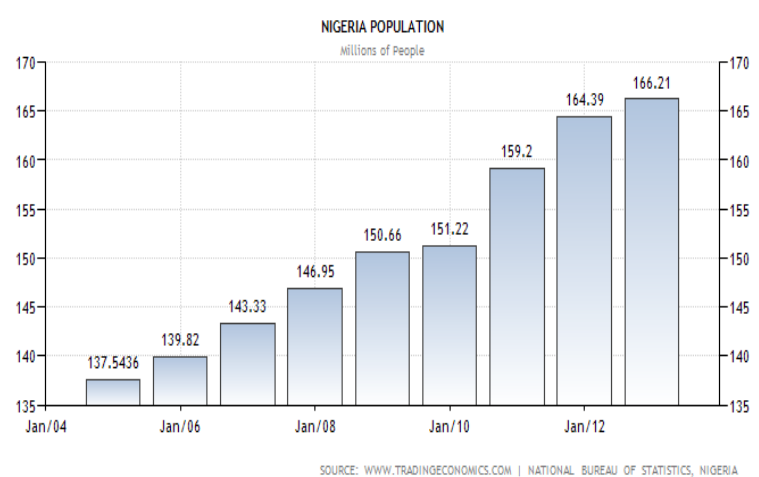

Fig. 1. Nigeria population growth rate since 2004. Source reference [7]

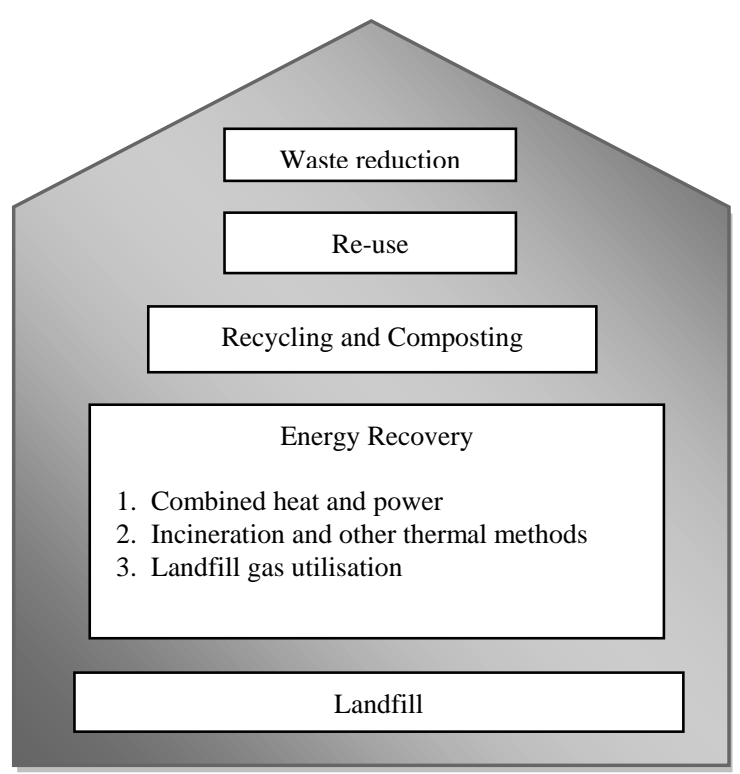

Fig. 2. Waste management hierarchy. Source Reference [3].

Waste disposal to uncontrolled landfill is still the primary waste management technology adopted in most African countries [4], without energy recovery. The so-called landfills are merely dumpsites lacking appropriate engineering design and construction. These have now become a concern, as the menace of the 'landfills', is worse than the nuisance constituted by the waste along streets. The issue of concern is that landfill remains the primary and perhaps the only treatment method practiced in most of parts Africa. Although Africa is the least contributor to the world green house gas emission, it is considered the most vulnerable to climate change effects [1]. Therefore the need for clean energies in Africa cannot be overemphasized.

\section{B. Landfilling in Africa and Resulting Environmental Impacts}

Landfills are basically physical facilities being used to dispose residual solid waste, in the surface soils of the earth [8]. Many countries of the world uses landfill as the largest route of municipal solid waste disposal including the UK, Portugal, Italy, Spain, Finland and many others [3]. In most
African countries, uncontrolled landfills, open dumpsites and open burning (Fig. 3) are still the key waste management practices, where scavengers pick a few valuable materials and recycle them [9].
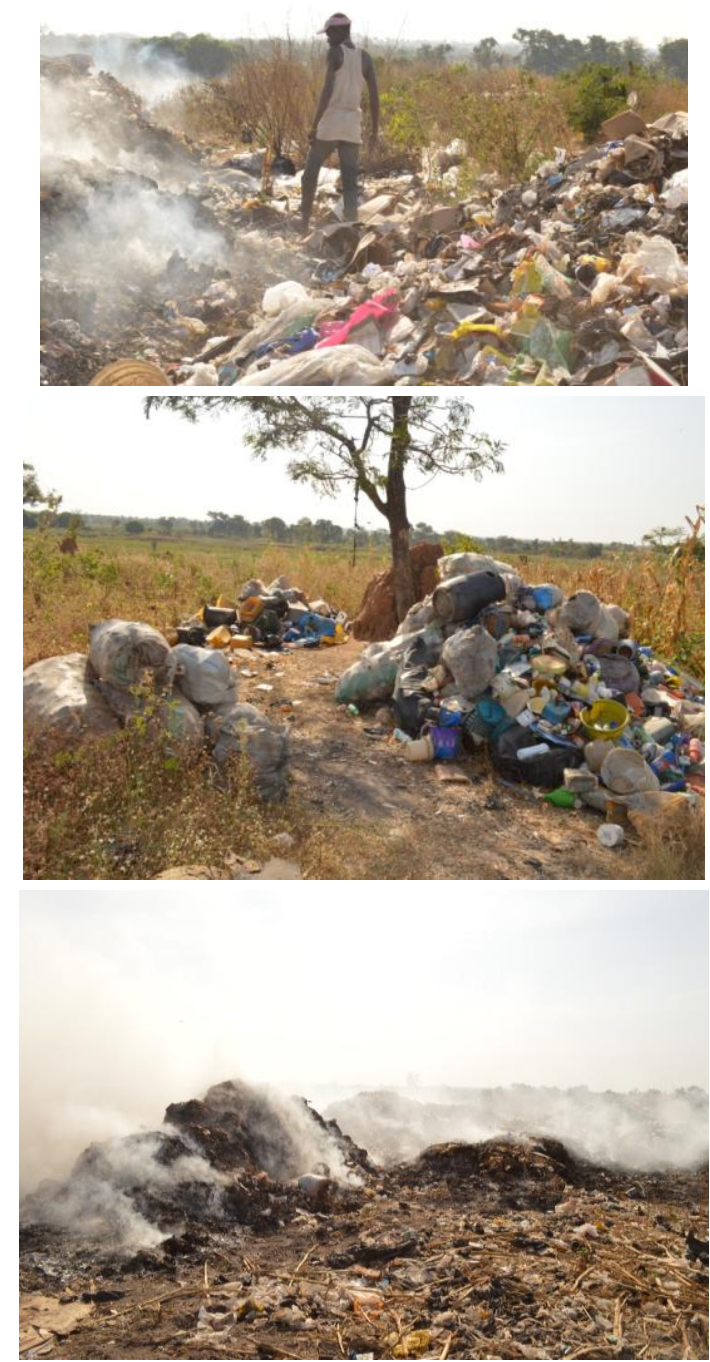

Fig. 3. Typical municipal waste dumpsite, located in Minna, the capital city of Niger State, Nigeria; showing the activity of a scavenger and a pile of scavenged materials. (Photos taken in December 2013).

Waste sent to these landfills (dumpsites) comprises biodegradable waste, medical waste as well as non-biodegradable waste. A number of biological, chemical and physical reactions are carried out on the solid wastes deposited in the landfills, giving rise to production of greenhouse gases. The biochemical decomposition on the biodegradable waste by bacteria is the cause of greenhouse gas emissions (methane, carbon dioxide, and vinyl chloride), atmospheric pollution and environmental hazards [6]. Liquid percolation through the waste transports some of the compounds and dissolved materials to areas where they can more readily react. This poses great health risks to users of the immediate groundwater regime within the region.

The enhancement of disease vectors' breeding zones in mismanaged landfills further creates health problems [8]. These factors and many others arouse concerns with the use of landfills as treatment options. As a result, in many parts of the world solid waste is as much as possible taken out of the 
landfills, leading to the shutdown of some of the landfills.

Most African countries abstract groundwater for both agricultural and domestic purposes and in some cases industrial purposes. Leachate from the landfill into the underlying groundwater has been reported to cause a number of problems, especially for settlers within the vicinity of the so called landfill. This also poses great danger to human health resulting from the crops grown with irrigated water abstracted from leachate polluted regions. These negative effects are the compelling forces for the reduction of the biodegradable and recyclable portion of municipal waste taken to the landfills [10]. A global attention is now been turned into adopting measures that will in every way possible reduce greenhouse gas emissions, one of which is the reduction of waste sent to a landfill.

This means modern technologies have to be employed not just to manage solid waste but also to recover the energy from it. Reference [6] also reported that even with state of the art technologies employed to some landfills, such as liners, leachate collection systems are still a problem. Therefore if organic waste can be diverted from the landfills, the environment would be safe from a great measure of greenhouse gases, with reduced environmental and health issues and therefore the non-biodegradable materials can be better managed.

In view of this, a number of world commitments such as the Kyoto protocol which was first held in Kyoto, 1997 to reduce the green house gas emissions and revised in
November, 2006 in Nairobi (Kenya) stressed the adoption of clean development mechanisms in tackling the greenhouse effect [1].

\section{Anaerobic Digestion}

Anaerobic digestion is the breaking down of organic material in the absence of oxygen. Anaerobic digestion is about the most environmentally friendly treatment of food-waste [11]. A series of step-by-step biochemical reactions catalyzed by micro-organisms causes organic material breakdown [12]. The entire anaerobic digestion process produces biogas; which comprises methane and carbon-dioxide and a digestate; which is also rich in some macro-nutrients (nitrogen and phosphorus) needed for plant growth. Anaerobic digesters are operated at a mesophilic $\left(35^{\circ} \mathrm{C}-40^{\circ} \mathrm{C}\right)$ and thermophilic $\left(55^{\circ} \mathrm{C}-60^{\circ} \mathrm{C}\right)$ temperature respectively [11]. The $\mathrm{AD}$ used to be an option for waste stabilization and a means of reducing the amount of waste sent to landfills, but a range of products are now been optimized from the $\mathrm{AD}$, such as electricity, heat, biofuels; Ethanol, Butane and Acetate, Methane gas for domestic use not leaving out the agricultural fertilizer supplements.

\section{Comparison between Anaerobic Digesters and Landfills}

By-products of similar chemical compositions are generated from both the anaerobic digester and the landfill in gaseous, solid and liquid forms (Fig. 4).

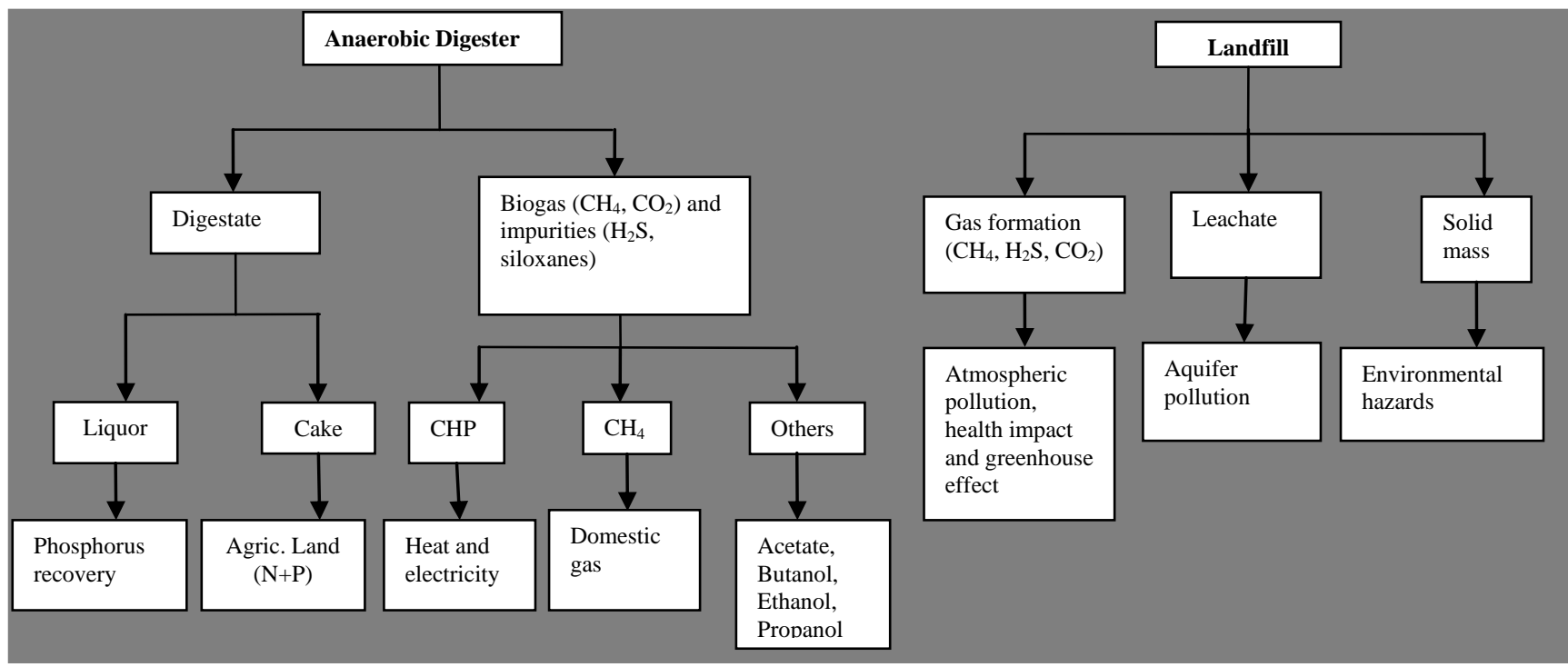

Fig. 4. Anaerobic digester and landfill outputs and their resultant effects.

\section{1) Gaseous phase}

Gaseous products primarily methane, carbon dioxide and hydrogen sulphide are generated both within the anaerobic digesters and landfills [8]; while these gases are carefully and systematically collected and cleaned up into useful energy forms in the case of anaerobic digesters, they gradually diffuse into the atmosphere from landfills especially for uncontrolled landfills and open dumpsites. The effects are therefore seen in impaired air quality in the landfill vicinity and also greenhouse effect and global warming [6].

\section{2) Liquid phase}

The leachate from landfill (liquid product) which is site and waste dependent and the digestate liquor from anaerobic digestion are equally hazardous and can be a huge nuisance. Leachate seeps through the piled waste carrying along with it some end products of metallic reduction and organic decomposition of the waste materials and percolates into the soil below the wastes. The resultant effect is the pollution of groundwater. On the other hand, the anaerobic digester is a more controlled system, whereby the liquid product is recovered, which can be treated onsite or offsite with the recovery of nitrogen and phosphorus.

\section{3) Solid phase}

The feedstock for the anaerobic digesters being organic 
makes the solid phase quite different from that of the landfills which has a combination of all manner of waste types. A digestate is produced from the anaerobic digestion process which can be fed directly to farm lands as a fertilizer supplement. This is especially good for farmers who are not financially able to buy processed fertilizer. On the other hand the landfill just leaves heap of waste which constitute nuisance and occupies the ever reducing land resource.

\section{E. Net Present Value for Energy Recovery from Landfill}

Reference [13] reported the price of natural gas at N3, 000 per $12.5 \mathrm{~kg}$ cylinder in Nigeria. Reference [14] also reported that the price of cooking gas now sells between N3,000 to
$\mathrm{N} 3,600$ per $12.5 \mathrm{~kg}$ cylinder. The increase in cost of natural gas gives a reason to worry and source for other options for gas generation other than fossil fuels.

Middle income countries generate the most organic waste; therefore they have the highest potential for AD feedstock. Reference [4], reported the waste generations from seven major cities in Nigeria (Table I), this compliments the report that high income countries generate $85,000,000$ tons of municipal solid waste, middle income countries, 34,000,000 tons and low income countries 158,000,000 tons annually, with 28 percent, 58 percent and 41 percent organic fractions respectively [15].

TABLE I: COMPOSITION OF WASTE STREAMS CHARACTERISTICS

\begin{tabular}{|c|c|c|c|c|c|c|c|}
\hline City & Organic (\%) & Plastic (\%) & Paper (\%) & Textile (\%) & Metal (\%) & Glass (\%) & Others (\%) \\
\hline Nsukka & 56.0 & 8.4 & 13.8 & 3.1 & 6.8 & 2.5 & 9.4 \\
\hline Lagos & 56.0 & 4.0 & 14.0 & -- & 4.0 & 3.0 & 19.0 \\
\hline Makurdi & 52.2 & 8.2 & 12.3 & 2.5 & 7.1 & 3.6 & 14.0 \\
\hline Kano & 43.0 & 4.0 & 17.0 & 7.0 & 5.0 & 2.0 & 22.0 \\
\hline Onitsha & 30.7 & 9.2 & 23.1 & 6.2 & 6.2 & 9.2 & 15.4 \\
\hline
\end{tabular}

Others $=$ dust, ash, ceramic, rubber, soil, bones.

Source: Reference [4].

The NPV was calculated using the following equation;

$$
\begin{gathered}
\mathrm{NPV}=-C_{0}+\Sigma\left[C_{t} /(1+i)^{t}\right] \\
\mathrm{NPV}=-C_{0}+A\left[(1+i)^{N} / i(1+i)^{N}\right]
\end{gathered}
$$

where $C_{\mathrm{o}}=$ capital cost, $N=$ time (years), $i=$ discount rate, $A=$ annual cash flow and $C_{t}=$ net cash flow at time $t$.

\section{1) Capital expenditure (capex)}

The capital cost for landfill construction was assumed here as zero. This was because little or no engineering construction is currently been done for landfill construction, as virtually all of them are open dumps. The opportunity cost of the land used as dumpsite was also ignored because the cost of land varies from city to city and country to country.

\section{2) Annual cash flow}

TABLE II: OPERATING COSTS INCURRED IN COLLECTING AND

\begin{tabular}{|c|c|c|}
\hline \multirow[t]{2}{*}{ Item } & \multicolumn{2}{|c|}{ Type of vehicle } \\
\hline & Tipping trucks & Tractors \\
\hline Number of vehicle & 5 & 2 \\
\hline Trips/day & 2 & 2 \\
\hline $\begin{array}{l}\text { Quantity of petrol used } \\
\text { (L/day) }\end{array}$ & 25 & $* *$ \\
\hline $\begin{array}{l}\text { Quantity of diesel used } \\
\text { (L/day) }\end{array}$ & $* *$ & 25 \\
\hline Cost of fuel (\$) & 21.32 & $* *$ \\
\hline Cost of diesel (\$) & $* *$ & 21.76 \\
\hline $\begin{array}{l}\text { Maintenance cost } \\
\text { (\$)/vehicle/month }\end{array}$ & 88.24 & 88.24 \\
\hline
\end{tabular}
TRANSPORTING WASTE TO LANDFILL BY NISEPA

The annual cash flow was a combination of the operating cost incurred by the state environment agency and the cost of the environmental effect from greenhouse gases release. The operating cost was calculated from data obtained from the Niger state environmental protection agency (NISEPA), Nigeria (Table II). It included the cost of transporting waste to the dumpsite, fuelling and repair and maintenance. The labor cost was not considered since the workers are registered under a payroll in the Agency.

Reference [16] reported that 1tonne of organic waste sent to a landfill is equivalent to 1tonne of $\mathrm{CO}_{2}$ released. Following the clean development mechanism, shadow price of carbon is used to monetize the cost of carbon emissions in relation to its environmental impact. Reference [5] reported that the SPC currently ranges from $\$ 10$ to $\$ 30$, in order to achieve the $\mathrm{CO}_{2}$ emission baseline of $440 \mathrm{ppm}$ to $550 \mathrm{ppm}$. For the sake of this study, $\$ 10$ was adopted, since African countries are considered as least contributors to global warming.

Leachate release and percolation into the ground is environment and site specific, and also depends on time. This therefore differs greatly from place to place. It is therefore difficult to quantify the environmental effect of leachate, as such it was not considered in the appraisal.

The NPV for a 15-year period was calculated using (1) as -\$0.36million (-56, 107,144.33 naira).

\section{DISCUSSION}

\section{Advantages of the Anaerobic Digester for African Countries}

\section{1) Feedstock availabilty}

The feedstock is the primary requirement for an efficient anaerobic digester, which requires the right proportion of carbon to nitrogen ratio $(\mathrm{C}: \mathrm{N})$ for effective operation. A C:N ratio of about 15 to 20 is recommended for optimal operation. 
To achieve this, co-digestion of different waste types are employed.

In the UK for instance the department for food and rural affairs (Defra) outlines how the AD can help with meeting some key environmental and GHG emissions consent.

The feedstock used in developed countries has over the years been sludge arising, from primary and secondary settlement tanks and some amount of food waste, in order to balance the $\mathrm{C}: \mathrm{N}$ ratio. Africa is a continent with variety of foods, most of which are high in carbon, but unfortunately, all these end up in dumpsites. Even with the advent of crude oil, farming (animal and vegetative) still remains a major occupation of about 70 percent of the populace. These sources provide a viable feedstock for anaerobic digesters. Agricultural waste, farm slurries and food waste is a suitable combination for the feedstock $\mathrm{C}: \mathrm{N}$ ratio requirement in anaerobic digesters, which can be easily accessed in Nigeria.

\section{2) Temperature requirement and cost}

The appropriate temperature for bacteria to grow and feed is also a key criterion. The important point worthy of note is that anaerobic digesters are operated at high temperatures, as these enhance microbial activity. In cold countries, anaerobic digesters are used at average ambient temperature range of $-5^{\circ} \mathrm{C}$ to $10^{\circ} \mathrm{C}$. A lot of energy is therefore required to raise and maintain the digester temperature, as a result high capital and operating costs is required. The case is not the same with West African countries. In Nigeria, the average temperature ranges from $10^{\circ} \mathrm{C}$ to $35^{\circ} \mathrm{C}$, with relatively long hot periods. There is therefore high solar energy potential for anaerobic digesters as a clean development mechanism. Solar panels are now gaining attention in African countries as a means of renewable energy generation, yet much of this heat is left unutilized, this can therefore be explored in digesters. A hydraulic retention time of 15 to 20 days required to run the digester in cold countries in order to achieve optimum bacterial activity and biogas production, would be greatly reduced to about 4 to 5 days in Nigeria and most West African countries.

A much lesser energy will be required to raise and maintain the digester temperature compared to the cold countries and consequently, a cut in capital and operating costs. Also the same technology used to set up petrochemical plants is what is required for an anaerobic digester installation, as such since there is an existing expertise the cost of construction will be much lesser than it is in developed countries.

\section{3) Economic and environmental benefits}

The use of anaerobic digesters in West African countries will complement the unstable gas production and supply within the region from fossil fuel. Anaerobic digesters will also help in reducing the carbon footprint of the countries, thereby promoting healthy and safe working environment. The West African region is currently behind in her technology base approach to problem solving. The anaerobic digester will therefore be a step towards developing sustainable technology.

\section{CONCLUSION}

In conclusion anaerobic digesters prove to be the next step for municipal solid waste management in West African countries.

\section{ACKNOWLEDGMENT}

Cynthia Okoro-Shekwaga thanks the management of Niger State Environmental protection Agency, Nigeria for her maximum support in providing necessary information.

\section{REFERENCES}

[1] ECOWAS-SWAC/OECD, "Climate and climate change," Atlas on Regional Integration in West Africa, Environment Series, 2008.

[2] Encyclopaedia of Nations, Nigeria. [Online]. Available: http://www.nationsencyclopedia.com/economies/Africa/Nigeria.html

[3] P. T. Williams, Waste Treatment and Disposal, West Sussex, England: John Wiley and Sons Ltd., 2005, pp. 1-357.

[4] C. T. Ogwueleka, "Municipal solid waste characteristics and management in Nigeria," Iran. J. Environ. Health Sci. Eng., vol. 3, no. 3 , pp. 173-180, July 2009.

[5] N. Stern, "The economics of climate change," in Proc. One Hundred Twentieth Annual Meeting of the American Economic Association, 2008, vol. 98 , no. 2, pp. 1-37.

[6] H. Tammemagi, The waste Crisis; Landfills, Incinerators and the Search for a Sustainable Future, New York: Oxford University press 1999.

[7] National Bureau of Statistics Nigeria. On Nigerian population, trading economics. [Online]. Available: http://www.tradingeconomics.com/nigeria/population

[8] G. Tchobanoglous, H. Theisen, and S. Vigil, Integrated Solid Waste Management, Singapore: McGraw-Hill Book Co., 1993, ch. 11.

[9] The World Bank, "What a waste," Urban Development and Local Government Series, USA, 2012.

[10] A. G. Olayiwola, "Numerical simulation of mass flow of leachate, in a municipal solid waste fill - Part II: Vertical flow systems," Journal of American Science, vol. 6, no. 7, pp. 358-366, 2010.

[11] Defra. (2010). On anaerobic strategy and action plan. [Online] Available: http://www.defra.gov.org

[12] D. L. Russell, Practical Wastewater Treatment, New Jersey: John Wiley and Sons Inc., 2006, pp. 1-168.

[13] Premium times. (October 2012). [Online]. Available: http://premiumtimesng.com/business/102933-nigerian-cooking-gas-m ost-costly-in-the-world-gas-association-boss.html

[14] The Nigerian observer. (January 2014). [Online]. Available: http://nigerianobservernews.com/13012014/business/business3.html\#. UuQRssrLfIU

[15] T. Irena, H. E. Allen, A. A. F. Kettrup, and W. J. Lacy, Solid Waste Assessment, Monitoring and Remediation, London U.K: Elsevier Ltd, 2004, pp. 33-59.

[16] N. Horan, "Handling the digestate," CIVE5532M Wastewater and Organic Waste Management, University of Leeds, November, 2013.

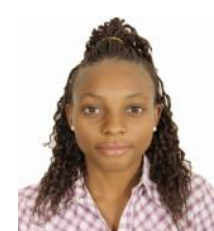

C. Okoro-Shekwaga was born in Minna, Niger State, Nigeria on December 4, 1988. She earned a B.Eng degree in agricultural and bioresources engineering from the Federal University of Technology, Minna, Niger State, Nigeria, in 2011. She is currently studying for an MSc.(Eng.) degree in environmental engineering and project management, in the University of Leeds, UK due by December 2014.

She worked at SearchFM 92.3, FUT Minna campus radio from 2009 to 2013 as a volunteer presenter. She worked as a freelance marketer for Enermart generators, Niger State from 2010 to 2011. She worked at the Nigerian Airspace Management Agency, Lagos State, Nigeria as an equipment engineer from 2011 to 2012 . She is currently a graduate assistant at the Federal University of Technology, Minna, Niger State, Nigeria since 2012 till date. She has published a number of papers. She was a member of a team that researched on vehicular carbon emissions in minna and is currently running a research study on determining the energy potentials of waste materials in Minna landfill site. Her resaerch areas are energy from waste and green environment.

Mrs. Okoro-Shekwaga is a member of the Nigerian Institute of Agricultural Engineers. Mrs. Okoro-Shekwaga was elected as the chairperson of the Human Rights Council at the Nigerian Model United Nations conference in Abuja, 2009, where she received the award of the best female delegate; she was also awarded the best graduating crew member in 2012 by searchFM 92.3 FUT Minna campus radio. 